\title{
CPA Liability: A Crisis Of Confidence? Is The Auditor A Watchdog Or A Bloodhound?
}

Leslie E. Nunn, J.D., (E-mail: lnunn@usi.edu), University of Southern Indiana

\begin{abstract}
The recent problems with the financial status of Enron bring to mind when an accountant is liable for his or her work and to whom that liability can be directed. This paper analyzes most causes of action (rights to file a lawsuit) which can be claimed against an accountant. Most liability seems to stem from the auditing functions, but it can flow from a number of other causes as well. While the liability to the client is fairly straight forward, liability to third parties can be more treacherous. Among the legal principles on which liability can attach covered herein are breach of contract, negligence, negligent misrepresentation, intentional misrepresentation, unfair or deceptive trade practices, liability for incorrect tax returns, erroneous business advice, federal and state securities exchange acts, statutes of limitations, policy factors affecting court decisions, and damages.
\end{abstract}

\section{Introduction}

After four years of overstated profits totaling more than half a billion dollars, the collapse of Enron is the largest bankruptcy filing in the history of the United States. Arthur Anderson had audited those four years and approved the statements.

In the aftermath of the Enron fiasco, in December, 2001, Joseph F. Berardino, the CEO of Arthur Anderson accounting firm testified before a joint hearing of two subcommittees of the House Committee on Financial Services. Stating that some important information had not been disclosed by Enron during the audit process, Mr. Berardino went on to admit an error in judgment "appears to have been the result of a reasonable effort made in good faith." (Anderson CEO Testifies, by David S. Hilzenrath, December 12, 2001, The Washington Post newspaper)

What liability attaches to actions of a certified public accountant when financial documents prepared or audited turn out to be incorrect? This legal exposure comes in several forms, each of which is treated differently by the courts. Let us examine some of them. Accountants find themselves at risk primarily in preparation of the financial statements, and auditing financial statements.

\section{Fiduciary Duty Owed by an Accountant to the Client}

It is unquestioned that an accountant owes some duty to his client, but what is the legal nature of that duty? Uniformly, courts have held that it is a fiduciary duty that is owed to the client by an accountant. The fiduciary duty is the highest degree of care considered by law, meaning that the accountant owes the highest degree of care possible to his client and must deal with his client in the utmost good faith.

Readers with comments or questions are encouraged to contact the author via email. 
If the accountant foolishly or negligently mismanages money belonging to his client and a loss ensues, the accountant must make up the loss out of his own pocket. If with the same foolish or negligent mismanagement the client makes a tremendous profit, all of the profit goes to the client and none belongs to the accountant (absent an agreement to the contrary). The same is true for intentional mismanagement: the accountant must make up the loss from his own pocket, but all profits belong to the client and not the accountant.

Others who owe this highest degree of care to their clients include lawyers and trustees. Fiduciary cases can be found against accountants as well as lawyers, but the principles of law are the same. Taking a position against the best interest of one's client is a breach of that duty. A lawyer (or an accountant) commits a breach of trust going to the very essence of the relationship with the client when he takes a position adverse to that of his client or former client, in a business transaction. Matter of Roache, 446 N.E.2d 1302. Even when ending a relationship with a client, the lawyer (or accountant) must withdraw in such a manner as to least harm the client in order to protect the client's interests. Bailey v. Martz, 488 N.E.2d 716.

Putting it very succinctly, Justice Cardozo, of whom we will hear later, said that the fiduciary relationship requires "not honesty alone, but the punctilio of an honor the most sensitive. Meinhard v. Salmon, 249 N.Y. 458, 164 N.E. 545.

With this fiduciary duty in mind, let us now look at the legal relationship, from a liability standpoint, between the accountant and his or her client.

\section{Auditing}

The audit perhaps generates more lawsuits against accountants than any other cause. Courts look at the audit process as a process of verification of the financial statements. After reviewing the underlying records and the evidence that supports those statements, the accountant issues a letter that opines whether the statements fairly represent the financial status of the entity.

The audit process verifies the existence of reported assets, observes the business activities of the entity being audited, checks the account balances and arithmetic calculations, examines sample transactions, determines the propriety of the financial and accounting systems, verifies loans, accounts payable, accounts receivable, and otherwise does such investigative work as it deems necessary to determine the accuracy of the financial reports.

Since it is impossible to trace each and every accounting entry the planning and execution of an audit therefore require a high degree of professional skill and judgment. Just what to trace and how to trace it may vary from audit to audit, depending upon the type of business being audited. Likewise, when the audit is planned to be conducted in one fashion, questionable items turned up can dictate a change in the audit process to ensure the truthfulness and/or accuracy of those matters being reported.

The audit culminates in a letter, normally addressed to whomever asked for the audit, verifying the financial condition of the company and its statements. The letter includes the scope and opinion paragraphs, among others. Very generally stated, in the scope paragraph, the accountant certifies that the client has been examined in accordance with the GAAS, and the opinion paragraph discloses whether or not the audit has found the financial statements, taken as a whole, to be in conformity with GAAP and fairly presents all material aspects of the financial position, results of operations and changes in financial position of the client.

While the audit provides a check for the client on how well it is doing in its accounting functions, it also can provide a valuable function to others. As the United States Supreme Court stated in United States v. Arthur Young \& Co., (1984) 465 U.S. 805, 79 L.Ed.2d 826, 104 S.Ct. 1495, "By certifying the public reports that collectively depict a corporation's financial status, the independent auditor assumes a public responsibility transcending any employment relationship with the client. The independent public accountant performing this special function owes ultimate allegiance to the corporation's creditors and stockholders, as well as to the investing 
public. This 'public watchdog' function demands that the accountant maintain total independence from the client at all times and requires complete fidelity to the public trust." At pages 817-818.

\section{Breach of Contract}

To have a valid contract, five elements must be satisfied. There must be (1) an offer made, (2) an acceptance given, (3) consideration paid or given, (4) the parties must have the legal capacity to form the contract, and (5) the contract must be for a lawful purpose. For one party to sue the other for a breach of that contract, the court must first find that a legal and contractual relationship existed between the parties. That legal and contractual relationship is referred to as "privity.' Privity carries with it the understanding that the parties were in so close a relationship with each other due to the contract itself that they could rely upon each other and each owed the other a duty to perform fully under the terms of the contract. Only if that privity exists can one party to a contract sue the other party of the contract for a breach thereof.

The notable exception is in third party contracts. These are contracts where two people enter into a contract for the sole benefit of a third person (e.g. Mary contracts with Sam for Sam to paint Jane's house). In the example, Jane is referred to as a third party beneficiary since she is not a direct party to the contract, but the contract is for her benefit. Here, either of the two parties to the contract or the third party beneficiary can file suit to enforce the contract or for a breach of it.

Each party to the contract has a duty to perform the contract exactly as required by the terms of the contract. As seen below, the word "duty" comes up again in the negligence discussion. In contracts, the duty is to do or refrain from doing something as the contract requires, and does not consider the consequences to the other party or anyone else, if it is accomplished consistent with the terms of the contract. If, when finished, the thing done does not help the other party as desired, payment must still be made, if the work was accomplished in accordance with the terms of the contract. In negligence, we look to the effect the action had on someone else to help determine liability. That is not necessarily so in contracts.

\section{Implied Warranty or Covenant of Good Faith and Fair Dealing}

In all contracts, the courts require the parties to the contract to abide by the "strictures of good faith and fair dealing." This requires that "neither party shall do anything that will have the effect of destroying or injuring the right of the other party to receive the fruits of the contract." Anthony's Pier Four, Inc. v. HBC Associates, (1991) 411 Mass.451, 583 N.E.2d 806.

\section{Negligence}

Negligence is an unintentional tort like occurs when driving down a street, and a person accidentally runs a red light, crashing into another car. The driver did not intend to run the red light and certainly did not intend to crash into the oncoming car. Nevertheless, regardless of the driver's intent, the accident did occur. Negligence, then, refers to situations that happen accidentally. Four essential elements are necessary for any one to be found liable in a negligence case: (1) that the alleged wrongdoer owed a duty to the plaintiff, (2) that the alleged wrongdoer breached that duty, (3) that the plaintiff suffered injuries or damages, and (4) that the breach of the duty was the proximate cause of the plaintiff's injuries/damages.

This same four part test applies in accountants' negligence cases. The issue of did the accountant owe a duty to the client or third party can be a troublesome one for courts. An accountant (or a lawyer) must exercise towards his client the standard of care exercised by a reasonably prudent accountant (or lawyer). Only expert testimony (by another accountant or lawyer) can prove a breach of the standard of care. Onwuteaka v. Gill, 908 S.W.2d 276 (Texas 1995)

When the plaintiff is the client for whom the financial statements or audit was done, it is more easily determined whether the accountant is liable. Courts look to the relationship between the client and the accountant, 
what the accountant did and the resulting nature of the damage. Again, general negligence law is applied, the same as in the traffic accident example above.

However, the legal reasoning process becomes much more complicated when the person claiming injuries was not the client, but a third person who alleges he relied on the accountant's inaccurate work to his own damage. When it is claimed that an accountant negligently failed to find or report problems in an audit, the courts in the United States take one of three approaches to determine liability on the accountant's part: privity, intent to benefit third parties, or foreseeability.

From a technical point, one might ask is it accounting negligence or accounting malpractice being considered here. While many courts would not be too concerned about the distinction, the Ohio Court of Appeals in Scioto Memorial Hospital Assoc. v. Price Waterhouse \& Co., No. 90AP-1124 in 1993 took the opportunity to clarify the matter. "Although the briefs have referred to accountant 'malpractice,' more accurately, under Ohio law, we are concerned with accountant negligence, not 'malpractice' in the technical sense, although all professional negligence has sometimes been referred to as malpractice."

Also, in another case, the Ohio Supreme Court stated, "the common law meaning and legal definition of the term 'malpractice,' was limited to the professional misconduct of members of the medical profession and attorneys. Today, the term, malpractice, is sometimes used loosely to refer to the negligence of a member of any professional group. However, legally and technically, it is still subject to the limited common-law definition." Richardson v. Doe, 176 Ohio St. 370, 199 N.E.2d 878. It is doubtful that other courts would be similarly concerned. In any event, regardless of terminology, the legal principles can be summarized as follows:

\subsection{Privity of Relationship}

In 1922, a seller of beans asked a Mr. Shepard to verify the accuracy of a public scale he (Shepard) operated. The certificate of accuracy given by Mr. Shepard proved to be false as the scales did not weigh accurately. Mr. Glanzer, a buyer of beans (a third party to all of this) relied upon the certificate of weight accuracy and sued Mr. Shepard when it was learned that Glanzer had paid too much for the beans due to the inaccurate scale reading. The New York court held Shepard liable for negligence. This case was considered the "law" in New York for giving certificates of accuracy in other types of circumstances. Glazner v. Shepherd, 233 N.Y. 236, 135 N.E. 275.

Ultramares Corp v. Touche, 255 N.Y. 170, 174 N.E. 441 decided in 1931 was one of the first major cases where accountant's liability was considered. Ultramares made unsecured loans totaling $\$ 165,000.00$ to a company relying upon the audit opinion of Touche that the company's balance sheet correctly represented the financial condition of the borrower. Although the balance sheets showed a net worth of one million dollars, the company was insolvent. Shortly after the loans were made, the company filed bankruptcy and Ultramares lost most, if not all of its loaned money.

Chief Judge Cardozo of the New York court was one of the great jurists of his time. He pointed out that Touche knew the borrowing company was in need of cash and that the audit report would be presented to prospective lenders. In fact, Touche gave its client 32 copies of the letter opinion and its attachments. However, the client did not mention Ultramares by name or tell Touche about any actual or proposed credit with Ultramares.

Cardozo went on to find that there was no privity of contract between Touche and Ultramares, so Touche could not be liable to Ultramares for a breach of contract, and there was no contact between Touche and Ultramares that would almost equate a privity relationship, so Touche did not owe any duty to Ultramares. The court said there was no intentional wrongdoing on Touche's part, only an "honest blunder."

In defining the role of an accountant for an audit, Judge Cardozo stated, "If liability for negligence exists, a thoughtless slip or blunder, the failure to detect a theft or forgery beneath the cover of deceptive entries, may expose accountants to a liability in an indeterminate amount for an indeterminate time to an indeterminate class. The 
hazards of a business conducted on these terms are so extreme as to enkindle doubt whether a flaw may not exist in the implication of a duty that exposes to these consequences." 174 N.E. at page 444.

This New York ruling was further refined in 1985 in the case of Credit Alliance v. Arthur Andersen \& Co., 65 N.Y.2d 536, 483 N.E.3d 110. Before holding accountants liable to third parties who had no contractual relationship with the accountant, the New York court in Credit Alliance required (1) the accountant must have been aware that the financial reports were going to be used for a particular purpose or purposes, (2) in the furtherance of which a known party or parties was intended to rely, and (3) there must have been some conduct on the part of the accountant linking him to that party (almost to the privity requirement in contracts), which demonstrates the accountant's understanding of that party's reliance.

Questions then arise as to how much contact (or linking) there must be between the accountant and the third party for liability to arise. Only a few states follow this privity requirement, but in looking at a few of them, we can get an idea of what is necessary. Ohio requires that not only must the accountant have known of the existence of the third party, but that the accountant must actually give the report directly to the third party or act in some manner "specifically calculated to induce reliance" by the third party on the accountant's report. Haddon View Inv. Co. v. Coopers \& Lybrand, 70 Ohio St.2d. 154, 436 N.E.2d 212, at page 214-215.

In Security Pacific Business Credit, Inc. v. Peat Marwick Main \& Co., 79 N.Y.2d 695, 597 N.E.2d 1080, New York held in 1992 that a "mere unsolicited phone call" by a third party to an auditor is not sufficient to link the auditor and the third party for a liability suit to be maintained against the accountant. The accountant must be aware of the exact purpose for the audit being held and must act to further that purpose to the third party before liability attaches to the third person. In that case, there was no accountant's liability where the accountant had never provided or agreed to provide a copy of the audit report directly to the plaintiff, had not mentioned the plaintiff in its audit engagement letter with its client, and had shown no awareness that the audit would benefit primarily the plaintiff.

Ten states have been known to follow the privity test: Alabama, Arkansas, Idaho, Kansas, Maryland, Nebraska, New York, Ohio, Pennsylvania, and Utah. Additionally, federal courts in Colorado, Delaware, and Indiana have applied the law in their courts.

\subsection{Foreseeability}

The second manner in determining the liability of accountants to third parties in negligence cases is based upon the accountant's ability to foresee or anticipate that a third party (not the client) might come into possession of the audit report and rely upon it to his detriment, should it contain any incorrect information or opinions.

This approach was developed by Justice Howard Wiener in a law review article in 1983. Judge Wiener did not like the "anachronistic protection" given to accountants by courts and believed, instead, that if the accountant could have foreseen that the injured third party could have seen and relied to his detriment on the audit report, then the accountant should be liable. Wiener Common Law Liability of the Certified Public Accountant for Negligent Misrepresentation. (1983) 20 San Diego Law Review 233.

The New Jersey Supreme Court held that there was "no reason to distinguish accountants from other suppliers of products or services to the public and no reason to deny to third party users of financial statements recovce4ry for economic loss resulting from negligent misrepresentations. The auditors function has expanded from that of a watchdog for management of an independent evaluation of the adequacy and fairness of financial statements issued by management to stockholders, creditors, and others." Rosenblum v. Adler, 93 N.J. 324, 461 A.2d 138.

It is noted that the basis for liability considered by Judge Wiener and the New Jersey court is that of negligent misrepresentation. As will be seen below, this is a separate cause of action from that of true negligence. The line of reasoning in the foreseeability approach has not found favor among other jurists. 
Only three states have followed the foreseeability rule: New Jersey, Mississippi, and Wisconsin. At least four states have specifically refused to follow it: Florida, North Carolina, Washington, and West Virginia.

\subsection{Intent to Benefit Third Persons}

Under this rationale, the accountant must know the client intends to give the accountant's report to a third person. However, not every reasonably foreseeable user of the financial document may recover losses from the accountant for negligence. First the accountant must be informed that that specific third person will be receiving a copy of the financial report.

For the auditor to be liable to third parties in these jurisdictions, the accountant must have been informed of the client's intended use of the financial statements, accompanied by the auditor's opinion, to third parties (lenders, investors, shareholders, creditors, suppliers, etc.) before the audit report is given to the client, or in some cases, at the time the audit is contracted for between the accountant and client.

The exact requirements may vary from state to state, for different kinds of accountant liability cases can yield different results, even when applying the same rule of law. Dean William Prosser, the author of the Restatement of Torts, said "The problem is to find language which will eliminate liability to the very large class of persons whom almost any negligently given information may foreseeably reach and influence, and limit the liability, not to a particular plaintiff defined in advance, but to the comparatively small group whom the (accountant) expects and intends to influence." (Restatement Second of Torts, Tentative Draft No. 11, April 15, 1965. Section 552, p. 56)

When an accountant conducts an audit or prepares other financial statements which he or she knows will be given by the client to a third party, the accountant is clearly liable to the third party for errors in those reports which cause damage to the third party. In Arthur Andersen v. Superior Court of Los Angeles, 79 Cal.Rptr.2d 679, the accountant prepared an audit report on an insurance company knowing that those reports would be given to the Insurance Commissioner for California. Based on the audit report, which was incorrect, the Insurance Commissioner permitted the insurance company to continue in business when it otherwise would have closed it down, resulting in the loss to many people. The California Supreme Court permitted the Insurance Commissioner to proceed against the accountant on behalf of the creditors of the insurance company.

The AICPA Professional Standards, at Section 53.01 provide that "A distinguishing mark of a profession is acceptance of its responsibility to the public. The accounting profession's public consists of clients, credit grantors, governments, employers, investors, the business and financial community, and others who rely on the objectivity and integrity of certified public accountants to maintain the orderly functioning of commerce. This reliance imposes public interest responsibility on certified public accountants."

Further, this rule is consistent with the statements of the United States Supreme Court in U.S. v. Arthur Young \& Co., 456 U.S. 805, 104 S.Ct. 1495, 79 L.Ed.2d 826, when it said "By certifying the public reports s that collectively depict a corporation's financial status, the independent auditor assumes a public responsibility transcending any employment relationship with the client. The independent public accountant performing this special function owes ultimate allegiance to the corporation's creditors and stockholders, as well as to the investing public. This 'public watchdog' function demands that the accountant maintain total independence from the client at all times and requires complete fidelity to the public trust."

An excellent discussion of the Texas law and its evolution into adopting this rule can be found in the 1993 case of Brown v. KPMG Peat Marwick, 856 S.W.2d 742. Other states have followed similar reasoning to arrive at the same conclusion.

This rule of law appears to have the largest following of states. While this writer did not research each of the 50 states individually, a cursory review has disclosed 29 state and federal jurisdictions agreeing with it to date. The states include Alabama, Alaska, Arizona, California, Florida, Georgia, Hawaii, Iowa, Kentucky, Louisiana, 
Maine, Massachusetts, Michigan, Minnesota, Missouri, Montana, Nebraska, New Hampshire, North Carolina, North Dakota, Ohio, Pennsylvania, Rhode Island, South Carolina, Tennessee, Texas, Utah, West Virginia, and Wisconsin.

\section{Negligent Misrepresentation}

Negligent misrepresentation is a tort totally separate from negligence. Negligent misrepresentation comes into play where the accountant makes what turns out to be a false statement, honestly believing it to be true, but without reasonable ground for that belief.

To win a lawsuit for negligence misrepresentation, the plaintiff must prove that the defendant accountant (1) in the course of business, (2) supplied false information for the guidance of others, including the plaintiff, (3) in their business or transactions, (4) causing and resulting in pecuniary loss to the plaintiff, (5) by his justifiable reliance upon the information, and that the accountant (6) failed to exercise reasonable care or competence in obtaining or communicating the information. Golber v. BayBank Valley Trust Co., (1999) 46 Mass.App.Ct. 256, 704 N.E.2d 1191.

We are speaking here of positive assertions of facts. Examples would be opinions expressed by someone who possesses or holds himself out as possessing superior knowledge or special information or expertise regarding the subject matter and a plaintiff who can reasonably rely on the supposed knowledge, expertise or information of the defendant's representations. Cohen v. S \& S Construction Co., 201 Cal.Rptr. 173. It must be noted that the person entitled to rely upon the questioned statement, must be one of those to whom or for whom the misrepresentation was made in the first place. And, the professional, to be liable, must manifest in some clear fashion that he or she is acting to benefit the third party in a specific and defined transaction. As it relates to a third party who claims damages because he relied upon an opinion statement of an accountant, that reliance must be actual and justified. Without the reliance, there can be no recovery, regardless of how poorly or fraudently the audit was conducted by the accountant. Garcia v. Superior Court, 268 Cal.Rptr. 779, 789 P.2d 960.

Accountants are not the only professionals facing the possibility of liability for negligent misrepresentation. Other professionals similarly positioned would include lawyers, architects, engineers, title insurers, physicians, and the like.

But even here, some states require before the accountant can be found liable, that there exist a relationship between the accountant and the plaintiff of privity or near privity. New York requires proof that (1) the accountant was aware that his representations would be used for particular purpose; (2) that the accountant intended that a known party or parties would rely on his representations in furtherance of that purpose; and (3) that there was some conduct on the part of the accountant linking him to that party, which evinces the accountant's understanding of that party's reliance. In re JWP Sec. Litig., 928 F.Supp 1239 (S.D.N.Y. 1993).

\section{Intentional Misrepresentation}

These cases usually arise where it is alleged that the accountant is a "co-conspirator" with his client in intentionally misleading third parties as to the true condition of the client. The key element is knowledge or intent on the accountant's part. In law, this is referred to as "scienter." If the accountant has no belief in the truth of his opinion or statements, and makes them recklessly, without knowing whether or not they are true or false, then the requirement of scienter is met and satisfied. Fraud is found also where the accountant makes a suggestion of fact that is not true and the accountant does not believe it to be true when he or she makes it.

Knowledge would be based on actual knowledge or what the accountant should have known. What he should have known is based in part on his professional obligations. The professional standards of the American Institute of Certified Public Accountants, Section 220.03, provides: "It is of utmost importance to the profession that the general public maintain confidence in the independence of independent auditors. Public confidence would be impaired by evidence that independence was actually lacking, and it might also be impaired by the existence of circumstances which reasonable people might believe likely to influence independence. To be independent, the 
auditor must be intellectually honest; to be recognized as independent, he must be free from any obligation to or interest in the client, its management, or its owners. Independent auditors should not only be independent in fact; they should avoid situations that may lead outsiders to doubt their independence.

Who can claim foul against the accountant in this instance? Section 531 of the Restatement Second of Torts provides that "One who makes a fraudulent misrepresentation is subject to liability to the persons or class of persons whom he intends or has reason to expect to act or to refrain from action in reliance upon the misrepresentation, for pecuniary loss suffered by them through their justifiable reliance in the type of transaction in which he intends or has reason to expect their conduct to be influenced."

\section{Unfair or Deceptive Trades Practices Acts}

Most states have statutes defining what trade practices are considered to be unfair or deceptive in nature. That proscribed conduct on the part of a person also applies to accountants. What is and what is not unfair or deceptive will usually vary from state to state. Here we look at only a couple of cases to illustrate the point.

In Texas, the 1995 case of Thompson v. Deloitte \& Touche, 902 S.W.2d 13, considered this very subject. The plaintiff's father owned a company. The Defendant Deloitte \& Touche was his company as well as personal accountant. Shortly before his death, the father met with the Defendant accountants, his attorney and his stockbroker, making significant changes to his will, as it affected his daughter (the plaintiff in this case). Upon his death, the changes became known and the daughter sued Deloitte \& Touche, claiming among other things that the accountant violated the Texas deceptive trades act.

The Supreme Court of Texas held that in order to win, a plaintiff must be a consumer, being one who has sought or acquired goods or services by purchase or lease. Those goods or services must form the basis of the plaintiff's complaint. In analyzing the complaint, the Court said the daughter alleged that the accountant should have told her of the father's desire to change his will so she could have stopped him. Since the daughter's concern was that she had not been told that her father was changing his will, the service of advising on the will change was not at issue. Further, it was the father who had hired the accountant, and not the daughter. Therefore, the daughter did not meet the tests to successfully prosecute her lawsuit and it was dismissed.

In Connecticut, a conflict of interest claim is a negligence claim against the accountant and a negligence claim cannot amount to an unfair trade practice, because the deviations from standards of care for accountants are not situations the unfair trade practices acts were designed to prevent. Advest Group, Inc. v. Arthur Andersen, CV 970571417, Connecticut Superior Court, decided July 20, 1998.

\section{Liability for Taxpayer who Relies on Accountant's Incorrect Tax Return}

In Richlands Medical Assoc v. Commissioner of Internal Revenue, 1992 U.S.App.Lexis 1171, The United States Court of Appeals for the Fourth Circuit issued its opinion on the issue of liability of taxpayers when they have an accountant prepare their tax returns. Here the executives of Richlands Medical Association were taxed because of "excessive" compensation paid to them by Richlands. These executives protested, claiming that the tax return had been prepared and filed by their accountant. After a trial, the U.S. Tax Court ruled against the taxpayer.

The Court of Appeals noted, that the record from the Tax Court did not show that the officers of Richlands sought or received any advice from their accountant regarding allowable compensation deductions. And, the record did not contain any evidence that Richlands' executives ever discussed this issue with their accountant. Finally, the Court of Appeals found that there was no evidence that the executives of Richland had ever made a full disclosure of all relevant facts to their accountant so that he could give an informed opinion on that issue to Richlands and its executives. Therefore, the Court of Appeals affirmed the Tax Court's decision against the taxpayer.

The lesson to be learned here, from the accountant's standpoint, is to make sure at a trial on tax matters, the court record clearly includes all matters and evidence which are relevant to the relationship which the accountant 
had with his client. As in Redlands, the accountant should testify and present evidence as to what the client did and did not communicate, what documents were and were not provided by the client, and all other matters which can reflect favorably on the accountant.

This is a good example of the importance of detailed record keeping while conducting the audit. The notes can, in most instances, be introduced in court, provided they were made contemporaneously with the events that occurred, and certain other requirements are met.

In passing, it is noted that the Richlands court favorably cited the Tax Court case of American Properties, Inc. v. Commissioner, 28 T.C. 1100 , affirmed by the $9^{\text {th }}$ Circuit Court at 262 F.2d 150 , to the effect that while a showing of honesty, good faith, and disclosure by the taxpayer to his accountant may preclude the existence of fraud, good faith alone does not always preclude the negligence penalties.

\section{Erroneous Business Advice Given by a CPA to His Own Client}

What happens when an accountant gives advice to his client in an area which is clearly beyond his field of expertise? This occurred in the United States Tenth Circuit Court of Appeals case of Gilmore \& Wilson Construction Co v. Commissioner of Internal Revenue, No. 97-9024, 9026, 9027, decided on January 13, 1999.

Gilmore considered investing in a company to be formed ("Southeast') for the purpose of purchasing a plastics recycling business. Gilmore's accountant did not give his client any investment advice. Nevertheless, Gilmore asked the accountant to look into the plastics recycling business. None of Gilmore's officers or employees visited the recycling business or did any due diligence work at all to investigate the propriety of the purchase. The accountant was paid by the new company Southeast, and not by Gilmore. If the accountant had done any due diligence search, his advice surely would have been to not purchase the business. However, the accountant was a tax accountant, and had no due diligence investigation or other business expertise at all.

The accountant did visit the recycling company and talked with the owners. For several minutes he viewed a demonstration of the prototype machine which was the main portion of the business. The court found the accountant did nothing more than to rely on the statements of the business promoters and offering materials. The documents given to the accountant by the sellers clearly warned that the Internal Revenue Service would likely challenge the value placed on the recycler as it lacked market controls. However, even with this warning, the accountant did nothing to verify the value of the recycler.

The Tenth Circuit noted the Fifth Circuit's concern that if a court requires "moderate-income investors to independently investigate their investments, the start-up investigation costs may prevent them from investing at all. If the costs do not prohibit entry, these investors still may not invest because the investigation costs may far exceed their potential profit." Heasley v. Commissioner, 902 F.2d 380.

Also, in Anderson v. Commissioner, 62 F.3d 1266 (10 $0^{\text {th }}$ Cir. 1995), the court held that "one does not have to be an expert in an industry before he can invest in the industry himself or recommend an investment to another" person. In Gilmore the court went on to say that taxpayers do not need to monitor the efforts of their advisors when their experts are acting in the areas of their expertise. Further, the fact the accountant could also receive compensation from the Southeast (the company in which Gilmore was considering investing) alone did not make the taxpayer's reliance on his advice unreasonable in and of itself.

Citing a line of cases, the court held that moderate-income investors do not have to investigate their investments themselves, but may rely on the appropriate advice of financial advisors and accountants, when that reliance is objectively reasonable and justifiable. For this to be, the advice must fall at least generally within the advisor's areas of expertise, the advisor must be independent of the investment, and the relative sophistication of the taxpayer are considerations in determining whether or not the reliance is reasonable. 
Unfortunately for Gilmore, the due care which should have been taken was not the tax consequences of the purchase of the recycling business, but the economic advisability of purchasing it at all. The court said the red flags raised in the warning of the sales literature was enough to put any one on notice, especially college-educated, successful businessmen like the taxpayer. With the combination of the accountant's lack of knowledge of the plastics recycling business, and his general lack of knowledge and experience in the area of investigating potential business investments, taken together made it unjustifiable for Gilmore to have relied on the accountant.

\section{Securities Exchange Acts}

When it involves securities (for instance, corporations) whose ownership interests are sold to the public in general, the Securities Exchange Act applies. This act of Congress has several specific provisions permitting lawsuits to be filed by investors and others against certain individuals, including accountants. Enacted to protect the investors, the Act imposes liability on accountants in specific situations and pretty much treats accountants' liability as is done in negligence cases.

Many states also have their own securities exchange acts, usually patterned after the federal law. Since those acts vary from state-to-state and time does not permit an analysis of each of them, following is a consideration of the major liability provisions found in the federal Securities Exchange Act of 1934, as amended.

\subsection{Section 10(b)}

An accountant can be liable in 10(b) violations, but he or she must do more than simply fail to follow GAAP, or it is not a 10(b) violation. To succeed, the plaintiff must plead and prove enough facts to amount to recklessness such that the recklessness approximates intent. Jacobs v. Coopers \& Lybrand, 97 Civ. 3374 (1999, N.Y.)

An accounting firm possesses a "due Diligence" defense in Section 10(b) cases, which can be used to escape liability if the accountant can show he or she had "after reasonable investigation, reasonable ground to believe and did believe" its statements were not misleading." In re Cendant Corp. 109 F.Supp.2d 235 (2000 New Jersey)

The United States Supreme Court has held that accountants can be held liable to the actual purchasers or sellers of securities for fraud and gross negligence. Ernst \& Ernst v. Hochfelder, 425 U.S. 185, 47 L.Ed.2d 668, 95 S.Ct. 1917

\subsection{Section 11}

This section provides in part "In case any part of the registration statement ... contained an untrue statement of a material fact or omitted to state a material fact required to be stated therein or necessary to make the statements therein not misleading, any person acquiring such security (unless it is proved that at the time of such acquisition he knew or such untruth or omission) may.... sue ... every accountant... or any person whose profession gives authority to a statement made by him, who has with his consent been named as having prepared or certified any part of the registration statement, or as having prepared or certified any report or valuation which is used in connection with the registration statement...."

It is important to note that the accountant's liability is limited to situations in which he or she prepares or certifies the accuracy of a portion of a registration statement and thus is aware he or she is creating part of a communication to the public: liability is limited to third persons who actually purchase the questioned security; damage exposure is limited to the out-of-pocket loss suffered by the purchaser and can be no greater than the amount of the offering. 15 U.S.C. Section 77(a), (e) and (g). 


\subsection{Section 18}

This section of the Securities Exchange Act imposes liability on accountants for any misstatement contained in any document filed with the SEC, but the liability is limited to third persons that have relied on the accountants' statement when they sold the security at a price that was affected by the misstatement.

\section{Statute of Limitations}

When the client or third party claims an accountant has caused him harm, there is a time limit on how long the alleged injured party can wait before filing a lawsuit. This time limit is covered by state statute. The limit not only varies from state to state, but also varies from type of claim to type of claim. In other words, the time limit might be different for a breach of contract claim than it is for a negligence claim. Again, this is controlled by statute.

The courts are repeatedly faced with the issue of has the lawsuit by a client been filed in a timely fashion, or did the client wait too long. If the time period has passed, the lawsuit will be dismissed provided the accountant raised the defense of statute of limitations in his or her Answer filed in court to the Compliant against them. It is noted in passing that statute of limitations per se is not normally a valid defense to a grievance claim of misconduct filed against an accountant before a state board of accountancy.

In determining whether or not the lawsuit was filed too late in violation of the statute of limitations, the court looks to the issue of when the cause of action arose. This means, when did the plaintiff client or third party first have the right to file the suit against the accountant. While this might sound like a simple question, in practice it can be far from that.

Normally, the cause of action (right to sue) accrues when a wrongful act causes some legal injury, even when the fact of injury is not discovered until later, and even if all of the resulting damages have not yet occurred. S.V. v. R.V., 933 S.W.2d 1 (Texas, 1996). Taking it out of the accountant's perspective, when does the cause of action occur when a surgeon leaves a sponge in the patient's abdomen after an appendectomy? When the sponge is left in there? When the patient knows or should have known of the sponge in his tummy? Or when the sponge in the tummy causes a problem?

If the cause of action does not accrue until the wrong is discovered or should have been discovered, this is referred to as the "discovery" rule. The discovery rule is applicable usually in cases of fraud or fraudulent concealment and where the injury is inherently undiscoverable but can be objectively verified. When it comes into play, the plaintiff's time limit does not begin until he knows or should have known of the wrong. Id. It is important to recognize that the law looks for the knowledge of the wrong, not when it is determined who did the wrong. Conceivably, it is possible to discover the wrong (triggering the time limit), and not be able to determine identity or location of the responsible party until after the time period has expired, thus precluding the filing of the lawsuit.

\section{Policy Factors Affecting Court Decisions}

So, when liability is found to exist, how far in degrees, people, relationships (or however you might like to measure the distance) should the liability extend? When this is determined, for what damages, real or imagined, should the plaintiff be permitted to recover? Courts in dealing with these questions refer to what policy is best for the public at large.

In viewing the important role of policy factors in determining negligence, the California Supreme Court noted that "there are clear judicial days on which a court can foresee forever and thus determine liability but none on which that foresight alone provides a socially and judicially acceptable limit on recovery of damages for an injury." Thing v. LaChusa, 48 Cal.3d 644, at p. 668, 865 P.2d 814 . This is a somewhat remarkable statement coming from a state that, at least to the lay mind, tends to find liability for "most" things. Even the more liberal courts, then, are 
reluctant to hold the accountant liable to all third persons that the accountant might have foreseen could use the accounting report.

In Bily v. Arthur Young \& Co, 3 Cal. $4^{\text {th }} 370,834$ P.2d 745 (1992), the California Supreme Court again hesitated to find liability in all an accountant's possible mistakes. The court stated "we decline to permit all merely foreseeable third party users of audit reports to sue the auditor on a theory of professional negligence. Our holding is premised on three central concerns: (1) Given the secondary "watchdog" role of the auditor, the complexity of the professional opinions rendered in audit reports, and the difficult and potentially tenuous causal relationships between audit reports and economic losses from investment and credit decisions, the auditor exposed to negligence claims from all foreseeable third parties faces potential liability far out of proportion to its fault; (2) the generally more sophisticated class of plaintiffs in auditor liability cases (e.g., business lenders and investors) permits the effective use of contract rather than tort liability to control and adjust the relevant risks through "private ordering;" and (3) the asserted advantages of more accurate auditing and more efficient loss spreading relied upon by those who advocate a pure foreseeability approach are unlikely to occur; indeed, dislocations of resources, including increased expense and decreased availability of auditing services in some sectors of the economy, are more probable consequences of expanded liability.

Even a century ago, reason was found in the accountant's work. One court in 1896 rightfully noted, "an auditor is a watchdog, not a bloodhound." 2 Ch.279, 288. It is particularly important to remember this in considering the manner in which most audits are conducted. The auditor goes to the client's place of business. There, in a location controlled by the client, the auditor sets to work. He talks to the client's employees regarding generalities as well as specific matters. The client controls the employees and, to be sure, the employees assisting the auditor are keeping their boss apprised of what the auditor is looking at and asking for. The client hires the auditor. The client pays the auditor's bill. It is the client's business that is being audited. It is even the client who decides who is going to see the audit report when it is completed. The auditor, then, is in many ways at the mercy of the client.

When a client hides unfavorable information, declines to disclose matters that could be harmful to a good report, truly misrepresents damaging situations, and otherwise makes it difficult or impossible for the auditor to get at the truth, serious problems can result. One might say that the auditor should simply withdraw and not complete the audit. That may be true when the auditor realizes what is going on while still in the process of conducting the audit. However, those cases probably never make it to court. By withdrawing, the auditor has removed himself from rendering an opinion of doubtful validity. Unfortunately, usually the auditor does not learn of the improper dealings of the client until long after the audit is completed and the opinion letter is delivered to the client.

Likewise, if it is difficult for third parties to recover their losses from an accountant, then presumably the third parties will be more prudent and careful in making investments. Permitting liberal recovery for an investor who fails to perform due diligence might be tantamount to rewarding carelessness in investing. Does it then follow that rewarding careless investing discourages sound investment and credit practices? Instead of Charles Darwin's survival of the fittest, does it become harboring of the weakest? If this approach is followed, what accountants will be willing to perform audits? Is the end result financial statements and balance sheets which cannot be relied upon by bankers, lenders, suppliers, investors, and others? Ultimately, what of our economy?

On the other hand, to prohibit recovery by third parties in every case, regardless of its nature, can have equally devastating results. Lenders may pull in their purse strings. Deliveries of supplies might become cash on delivery only. On and on one could go.

Clearly, then, either alternative carried to the extreme could be disastrous. A happy medium must be struck, and this is what the courts attempt. 


\section{Damages}

Damages vary, depending, in part, on whether the cause of action is arising out of a breach of contract, negligence, or other claim. If a breach of contract case, the aggrieved party is entitled to recover only such damages as are the direct and probable consequence of the breach of contract and that may reasonably have been in the contemplation of the parties at the time the contract was entered into. Stinn Chevrolet, Inc. v. Natl. City Bank, 28 Ohio St.3d 221, 503 N.E.2d 524 In negligence cases, damages are generally limited to losses suffered.

\section{Conclusion}

Accountants owe to their clients the highest duty of care possible - fiduciary duty. When the accountant breaches that duty, liability can result in financial reimbursement to the client for the losses sustained.

An accountant's liability to the client can be based on any of several causes of action (legal rights to sue) available to the client. First of all, the relationship between the accountant and client is based on contract. All contracts are interpreted by courts with an inherent promise or covenant of good faith and fair dealing on the part of the accountant and the client. The accountant can be liable if he or she breaches that contract by failing to do a proper job. If the accountant unintentionally causes harm to the client, he may be liable under the theory of negligence and/or negligent misrepresentation. Should the accountant intentionally misrepresent the financial condition, his or her liability is clear. A few states apply their deceptive or unfair trade practices laws to accountants. Generally, the Internal Revenue Service will not relieve a taxpayer for negligence penalties if the accountant makes a mistake on the taxpayer's tax return, or if the accountant gives business advice in an area where he or she has no expertise. Additionally, liability can be imposed by federal and state securities exchange acts when the client is a publicly held corporation or other regulated security.

Many lawsuits filed against accountants arise out of auditing functions. Not only does the client frequently sue, but third parties (e.g. lenders, investors, creditors, etc.) sue as well. Determining liability of the accountant to these third parties is more difficult. In the negligence area, courts follow one of three schools of thought: (1) some require a direct relationship (privity) between the accountant and the third party. (2) a few require that the accountant should have been able to foresee that the third person would see and rely upon the audit report, and (3) the majority of courts require that the accountant must have intended to benefit the third party before liability can be found.

Generally, the plaintiff (either a client or third party) must file his lawsuit against the accountant within a time limit specified by statute. Failure to do so precludes judgment against the accountant, even if there is clear liability.

In determining whether or not the accountant is liable, courts consider policy factors. Among them is the responsibility the accountant owes to the general public. While the client may be the business entity, it is well known that others utilize and rely on audit reports, including lenders, investors, creditors, etc. States take different approaches in applying those considerations to liability issues.

\section{References}

1. $\quad$ Advest Group, Inc.v. Arthur Andersen, CV 970571417, Connecticut Superior Ct, July 20, 1998

2. AICPA Professional Standards, Section 53.01

3. AICPA Professional Standards, Section 220.03

4. $\quad$ American Properties, Inc. v. Commissioner, 28 T.C. 1100,262 F.2d 150

5. Anderson CEO Testifies, by David S. Hilzenrath, December 12, 2001, The Washington Post newspaper.

6. Anderson v. Commissioner, 62 F.3d 1266

7. $\quad$ Anthony's Pier four, Inc. v. HBC Associates, (1991) 411 Mass. 451, 583 N.E.2d 806

8. $\quad$ Arthur Andersen v. Superior Court of Los Angeles, 79 Cal.Rptr.2d 679

9. $\quad$ Bailey v. Martz, 488 N.E.2d 716 
10. $\quad$ Bily v. Arthur Young \& Co., 3 Cal. $4^{\text {th }} 370,834$ P.2d 745

11. Brown v. KPMG Peat Marwick, 856 S.W.2d 742

12. Cohen v. S \& S Construction Co., 201 Cal.Rptr. 173

13. $\quad$ Credit Alliance v. Arthur Andersen \& Co., 65 N.Y.2d 536, 483 N.E.3d 110

14. Ernst \& Ernst v. Hochfelder, 425 U.S. 185, 47 L.Ed.2d 668, 95 S.Ct. 1917

15. Garcia v. Superior Court, 268 Cal.Rptr. 779, 789 P.2d 960

16. Gilmore \& Wilson Construction Co. v. Commissioner of Internal Revenue, No. 97-9024, 9026, 9027, decided January 13, 1999

17. Glazner v. Shepherd, 233 N.Y. 236, 135 N.E. 275

18. Golber v. BayBank Valley Trust Co., (1999) 46 Mass.App.Ct. 256, 704 N.E.2d 1191

19. Haddon View Inv.Co. v. Coopers \& Lybrand, 70 Ohio St.2d 154, 436 N.E.2d 212

20. Heasley v. Commissioner, 902 F.2d 380

21. In re Cendant Corp, 109 F.Supp.2d 235 (2000 New Jersey)

22. $\quad$ In re JWP Sec. Litig, 928 F.Supp 1239 (S.D.N.Y. 1993)

23. Jacobs v. Coopers \& Lybrand, 97 Civ. 3374 (1999, N.Y.)

24. Matter of Roache, 446 N.E.2d 1302

25. Meinhard v. Salmon, 249 N.Y. 458, 164 N.E. 545

26. Onwuteaka v. Gill, 908 S.W.2d 276 (Texas 1995)

27. Restatement of Torts

28. Restatement Second of Torts, Tentative Draft No. 11, April 15, 1965, Section 552

29. Restatement Second of Torts, Section 531

30. $\quad$ Richardson v. Doe, 176 Ohio St. 370, 199 N.W.2d 878

31. Richlands Medical Assoc. v. Commissioner of Internal Revenue, 1992, U.S. App.Lexis 1171

32. Rosenblum v. Adler, 93 N.J. 324, 461 A.2d 138

33. Scioto Memorial Hospital Assoc. v. Price Waterhouse \& Co., No. 90AP-1124 (1993 Ohio)

34. Securities Exchange Act of 1934, Sections 10(b), 11, and 18

35. Security Pacific Business Credit, Inc. v. Peat Marwick Main \& Co., 79 N.Y.2d 695. 597 N.E. 1080

36. $\quad$ S.V.v. R.V., 933 S.W.2d 1 (1996, Texas)

37. $\quad$ Stinn Chevrolet, Inc. v. Natl. City Bank, 28 Ohio St.3d 221, 503 N.E.2d 524

38. Thing v. LaChusa, 48 Cal.3d 644, 865 P.2d. 814

39. Thompson v. Deloitte \& Touche, 902 S.W.2d 13

40. $\quad$ Ultamares Corp. v. Touche, 255 N.Y. 170, 174 N.E. 441

41. United States v. Arthur Young \& Co., (1984) 465 U.S. 805, 79 L.Ed.2d 826, 104 S.Ct. 1495

42. Wiener, Common Law Liability of the Certified Public Accountant for Negligent Misrepresentation, (1983) 20 San Diego Law Review 233.

2 Ch. 279,288

15 U.S.C. Section 77 (a), (e) and (g) 